\title{
PENGARUH MODEL PEMBELAJARAN KOOPERATIF TIPE TALKING CHIPS TERHADAP KETERAMPILAN SOSIAL DAN HASIL BELAJAR IPS SISWA KELAS IV SEKOLAH DASAR
}

\author{
Nur Ainiyah $^{1}$, Rusijono ${ }^{2}$, Waspodo Tjipto Subroto ${ }^{3}$ \\ ${ }^{1}$ Mahasiswa Program Pascasarjana, Prodi Pendidikan Dasar, Universitas Negeri Surabaya, \\ ${ }^{2 \& 3}$ Dosen Pascasarjana, Prodi Pendidikan Dasar, Universitas Negeri Surabaya \\ e-mail: nur.10208@gmail.com
}

Received : November 2018

Reviewed : Desember 2018

Accepted : Januari 2019

Published : Januari 2019

\section{ABSTRACT}

The aims of this research is to know the effect of cooperative learning model of talking chips to social skill fourth grade student of Elementary School and to know the effect of cooperative learning model of talking chips to learning outcomes of Social Studies fourth grade student of Elementary School. The subject of this research is fourth grade student in SDN Kedungsumur I as control class and fourth grade student in SDN Kedungsumur III as experiment class school year 2015/2016. In this research using quasi experimental design with form of research is nonequivalent control group design. The research data was obtained as follows: social skills of student in pretest at experiment class there is nothing different with control class. This condition was shown with $t_{\text {hitung }}$ score $(0.613)<t_{\text {tabel }}(1.686)$ with mean score in experiment class is 58.3500 in control class 57.0500. While social skills of student in posttest at experiment class there is different with control class. This condition was shown with $t_{\text {hitung }}$ score $(14.081)>t_{\text {tabel }}$ (1.686) with mean score in experiment class is 86.5500 and in control class 63.3500. So, there are effect of the cooperative learning model of talking chips to social skills of student. After that for second hypothesis testing was showed that student learning outcomes in pretest at experiment class there is nothing different with control class. This condition was shown with $t_{\text {hitung }}$ score $(0.968)<t_{\text {tabel }}(1.686)$ with mean score in experiment class is 60.7000 and in control class is 57.3500. While student learning outcomes in posttest at experiment class there is different with control class. This condition was shown with thitung score (6.798) > t tabel (1.686) with mean score in experiment class is 89.6500 and in control class 74.1000. So, there are effect of cooperative learning model of talking chips to student learning outcomes. Based on the result of analyze data, it can be concluded that cooperative learning model of talking chips has an effect to student social skills and student learning outcomes in significant.

Keyword: Talking Chips, Social Skill, Learning Outcomes.

\section{ABSTRAK}

Tujuan penelitian ini adalah untuk menganalisis pengaruh model pembelajaran kooperatif tipe talking chips terhadap keterampilan sosial siswa kelas IV Sekolah Dasar dan untuk menganalisis pengaruh model pembelajaran kooperatif tipe talking chips terhadap hasil belajar IPS siswa kelas IV Sekolah Dasar. Subjek dalam penelitian ini adalah siswa kelas IV SDN Kedungsumur I sebagai kelas kontrol dan IV SDN Kedungsumur III sebagai kelas eksperimen tahun pelajaran 2015/2016. Dalam penelitian ini menggunakan quasi experimental design dengan bentuk desain penelitian nonequivalent control group design. Data hasil penelitian yang diperoleh sebagai berikut: keterampilan sosial siswa pada saat pretest di kelas eksperimen tidak ada perbedaan dengan kelas kontrol. Hal ini ditunjukkan dengan nilai thitung (0.613) < $t_{\text {tabel }}(1.686)$ dengan nilai mean pada kelas eksperimen sebesar 58.3500 dan pada kelas kontrol sebesar 57.0500. Sedangkan keterampilan sosial siswa pada saat posttest di kelas eksperimen ada perbedaan dengan kelas kontrol. Hal ini ditunjukkan dengan nilai $t_{\text {hitung }}(14.081)>t_{\text {tabel }}$ (1.686) dengan nilai mean pada kelas eksperimen sebesar 86.5500 dan pada kelas kontrol sebesar 63.3500. Jadi, ada 
pengaruh model pembelajaran kooperatif tipe talking chips terhadap keterampilan sosial siswa. Kemudian untuk pengujian hipotesis kedua menunjukkan bahwa hasil belajar siswa pada saat pretest di kelas eksperimen tidak ada perbedaan dengan kelas kontrol. Hal ini ditunjukkan dengan nilai $t_{\text {hitung }}(0.968)<t_{\text {tabel }}(1.686)$ dengan nilai mean pada kelas eksperimen sebesar 60.7000 dan pada kelas kontrol yaitu 57.3500. Sedangkan hasil belajar siswa pada saat posttest di kelas eksperimen ada perbedaan dengan kelas kontrol. Hal ini ditunjukkan dengan nilai thitung (6.798) > $t_{\text {tabel }}$ (1.686) dengan nilai mean pada kelas eksperimen sebesar 89.6500 dan pada kelas kontrol sebesar 74.1000. Jadi, ada pengaruh model pembelajaran kooperatif tipe talking chips terhadap hasil belajar siswa. Berdasarkan hasil analisis data, dapat disimpulkan bahwa model pembelajaran kooperatif tipe talking chips berpengaruh terhadap keterampilan sosial siswa dan hasil belajar siswa secara signifikan.

Kata Kunci: Talking Chips, Keterampilan Sosial, Hasil Belajar.

\section{PENDAHULUAN}

Pendidikan pada jenjang Sekolah Dasar merupakan jenjang awal peserta didik untuk mengembangkan pengetahuan dasar mereka ke jenjang yang lebih tinggi. Dalam kurikulum di Sekolah Dasar, mengembangkan tiga komponen yang penting yaitu aspek pengetahuan (kognitif), aspek keterampilan (psikomotor), dan aspek sikap (afektif). Ketiga aspek tersebut saling terintegrasi satu sama lain sehingga peserta didik diharapkan mampu mencapai tujuan pendidikan yang telah disusun oleh pemerintah kita.

Adapun tujuan pembelajaran IPS di Sekolah Dasar yaitu untuk membekali peserta didik untuk mengembangkan diri sesuai bakat, minat, kemampuan, dan lingkungannya serta siap menghadapi segala perubahan dan tantangan di masa depan. Sedangkan tujuan pendidikan IPS dalam kurikulum 2006 antara lain: (1) mengenal konsep-konsep yang berkaitan dengan kehidupan masyarakat dan lingkungannya, (2) memiliki kemampuan dasar untuk berpikir logis dan kritis, rasa ingin tahu, inkuiri, memecahkan masalah, dan keterampilan dalam kehidupan sosial, (3) memiliki komitmen dan kesadaran terhadap nilai-nilai sosial dan kemanusiaan, dan (4) memiliki kemampuan berkomunikasi, bekerjasama, dan berkompetisi dalam masyarakat yang majemuk di tingkat lokal, nasional, dan global.

Untuk memenuhi tujuan tersebut, guru hendaknya merencanakan suatu pembelajaran yang aktif dan bermakna untuk siswa agar mereka mampu dan memahami apa yang mereka pelajari serta tertarik untuk melakukan pembelajaran di kelas. Guru bisa mengembangkan pembelajarannya dengan menerapkan metode-metode atau model-model pembelajaran yang aktif dan inovatif sehingga peserta didik akan lebih terpacu dan bersemangat dalam melakukan pembelajaran di kelas. Selain itu dengan pembelajaran yang aktif dan inovatif, siswa akan lebih mudah memperoleh pembelajaran yang bermakna untuk kehidupan mereka dan siswa akan lebih mudah untuk memahami apa yang mereka pelajari saat ini.

Oleh karena itu, peneliti bermaksud mengadakan observasi tentang kondisi siswa di beberapa sekolah dasar di kecamatan Krembung kabupaten Sidoarjo. Observasi ini dilakukan guna menggali informasi tentang pola perilaku siswa di kelas saat pembelajaran IPS berlangsung. Kemudian peneliti juga melakukan observasi tentang model pembelajaran yang digunakan guru saat mengajar sehari-hari serta data hasil belajar IPS siswa.

Berdasarkan hasil observasi pada tanggal 9 Oktober 2015 disimpulkan bahwa pembelajaran IPS di sekolah dasar masih kurang menarik dan kurang efektif untuk peserta didik. Pembelajaran IPS yang dilakukan masih bersifat konvensional (teacher centered). Guru masih sering melakukan ceramah tanpa melibatkan siswa dalam proses belajar mengajar sehingga siswa terlihat bosan dan tidak bersemangat saat kegiatan pembelajaran. Siswa juga tidak memahami materi pembelajaran yang disampaikan guru karena guru tidak menggunakan model pembelajaran yang inovatif sehingga hasil belajar siswa juga menjadi rendah.

Kemudian, pada saat kegiatan pembelajaran guru jarang melakukan kegiatan berkelompok. Sekalipun ada kegiatan berkelompok, pada saat berkelompok siswa tidak dipantau dan dibimbing serta kegiatan berkelompok tidak berjalan efektif. Hal ini dikarenakan beberapa siswa yang pandai cenderung tidak percaya dengan kemampuan temannya untuk mengerjakan tugas sehingga tidak terjadi kegiatan berdiskusi dalam kelompok. Hal ini berakibat beberapa siswa yang memiliki kemampuan sedang menjadi tidak percaya diri untuk mengembangkan kemampuan mereka, takut untuk bertanya, berpendapat, dan menjawab pertanyaan-pertanyaan ketika kegiatan pembelajaran berlangsung. Suasana pembelajaranpun terlihat seperti 
persaingan antarsiswa pandai, yang mana siswa pandai selalu menjadi paling aktif dan siswa lain menjadi pasif di kelas. Hal ini menunjukkan bahwa kurangnya kerjasama antar siswa, sikap saling menghargai, dan kurang komunikatif baik dengan guru maupun dengan temannya sehingga keterampilan sosial siswa dikatakan masih rendah.

Berdasarkan masalah yang ditemukan, perlu pencarian solusi untuk memperbaiki kegiatan pembelajaran yang telah dilakukan. Dalam penelitian ini, peneliti menawarkan solusi yaitu dengan menggunakan model pembelajaran kooperatif tipe talking chips karena model pembelajaran ini merupakan model pembelajaran yang inovatif dan aktif untuk tipe pembelajaran kooperatif yang didalamnya dapat melatih siswa untuk meningkatkan keterampilan sosialnya secara merata.

Model pembelajaran kooperatif tipe talking chips adalah salah satu tipe pembelajaran kooperatif yang masing-masing anggota kelompoknya mendapat kesempatan yang sama untuk memberikan kontribusi mereka dan mendengarkan pandangan serta pemikiran anggota yang lain (Lie, 2008:63). Menurut Huda (2012:142), tujuan model pembelajaran kooperatif tipe talking chips adalah mengatasi hambatan pemerataan kesempatan yang sering mewarnai kerja kelompok. Hal ini sesuai dengan permasalahan yang ada. Oleh karena itu, melalui model pembelajaran ini diharapkan siswa dapat mengembangkan keterampilan sosialnya yaitu keterampilan berpendapat, menghargai pendapat teman, bekerja sama dalam kelompok dan meningkatkan hasil belajar IPS.

Pernyataan tersebut juga didukung oleh penelitian yang terdahulu yang telah dilakukan oleh Emy Yunita Rahma Pratiwi (2014) yang menyimpulkan bahwa model pembelajaran kooperatif tipe talking chips dapat meningkatkan hasil belajar siswa atau efektif diterapkan pada pembelajaran IPS tema berbagai pekerjaan subtema barang dan jasa di kelas IV.

Berdasarkan uraian tersebut, peneliti tertarik untuk melakukan penelitian dalam pembelajaran IPS dengan menggunakan sebuah model pembelajaran aktif dan inovatif dengan judul "Pengaruh Model Pembelajaran Kooperatif Tipe Talking Chips Terhadap Keterampilan Sosial dan Hasil Belajar IPS Siswa Kelas IV Sekolah Dasar".

Tujuan penelitian ini adalah untuk menganalisis pengaruh model pembelajaran kooperatif tipe talking chips terhadap keterampilan sosial siswa kelas IV Sekolah Dasar dan untuk menganalisis pengaruh model pembelajaran kooperatif tipe talking chips terhadap hasil belajar IPS siswa kelas IV Sekolah Dasar.

\section{TINJAUAN PUSTAKA}

Menurut Isjoni (2013:16) cooperative learning atau dalam bahasa Indonesia disebut pembelajaran kooperatif adalah suatu model pembelajaran yang saat ini banyak digunakan untuk mewujudkan kegiatan belajar mengajar yang berpusat pada siswa (student oriented), terutama untuk mengatasi permasalahan yang ditemukan guru dalam mengaktifkan siswa, yang tidak dapat bekerja sama dengan orang lain, siswa yang agresif dan tidak peduli pada yang lain. "During cooperative learning activities, the teacher circulated among the students listening and providing further feedback as needed" (Stevens dalam Gillies, dkk, 2008:98). Makna dari pernyataan tersebut adalah selama pembelajaran kooperatif, guru akan berkeliling untuk memantau, mendengarkan, dan memberikan umpan balik kepada siswa. Dalam hal ini guru berperan sebagai fasilitator untuk memfasilitasi siswa dalam diskusi kelompok yang mereka lakukan baik dalam bentuk bimbingan maupun motivasi untuk siswa.

Menurut Lie (2008:63) model pembelajaran kooperatif tipe talking chips merupakan salah satu tipe model pembelajaran kooperatif yang masing-masing anggota kelompoknya mendapat kesempatan yang sama untuk memberikan kontribusi mereka dan mendengarkan pandangan serta pemikiran anggota kelompok lain. Pernyataan ini juga didukung oleh pendapat Millis dan Cottel (dalam Fathurrohman, 2015:94) bahwa model pembelajaran kooperatif tipe kancing gemerincing (talking chips) adalah jenis model pembelajaran kooperatif dengan cara siswa diberikan chips yang berfungsi sebagai tiket yang memberikan izin pemegangnya untuk berbagi informasi, berkontribusi pada diskusi, atau membuat titik debat.

Adapun tujuan dari model pembelajaran kooperatif tipe talking chips menurut Huda (2012:142) adalah untuk mengatasi hambatan pemerataan kesempatan yang sering mewarnai kerja kelompok. Kebanyakan dalam suatu kelompok, seringkali ada satu siswa atau anggota dalam kelompok yang terlalu dominan dan banyak bicara, sehingga anak yang pasif hanya pasrah dengan siswa yang dominan.

Menurut Huda (2012:142-143) prosedur pelaksanaan model kooperatif tipe talking chips yaitu:

a. Guru menyiapkan satu kotak kecil yang berisi kancing-kancing (atau benda-benda kecil lainnya).

b. Sebelum memulai tugasnya, masing-masing anggota dari setiap kelompok mendapatkan 2 atau 3 buah 
kancing (jumlah kancing bergantung pada sukar tidaknya tugas yang diberikan).

c. Setiap kali anggota selesai berbicara atau mengeluarkan pendapat, dia harus menyerahkan salah satu kancingnya dan meletakkannya di tengah-tengah meja kelompok.

d. Jika kancing yang dimiliki salah seorang siswa habis, dan tidak boleh berbicara lagi sampai semua rekannya menghabiskan kancingnya masing-masing.

e. Jika semua kancing sudah habis, sedangkan tugas belum selesai, kelompok boleh mengambil kesepakatan untuk membagi-bagi kancing lagi dan mengulangi prosedurnya kembali.

Jarolimek (dalam Subroto, 2009:4) juga menyatakan bahwa "social studies have been defined as those portion of the social sciences selected for instructional purpose". Yang artinya bahwa IPS telah didefinisikan sebagai bagian dari ilmu-ilmu sosial yang dipilih untuk tujuan instruksional. Menurut Sapriya (2009:20) IPS di sekolah dasar merupakan nama matapelajaran yang berdiri sendiri sebagai integrasi dari sejumlah konsep disiplin ilmu sosial, humaniora, sains bahkan berbagai isu dan masalah sosial kehidupan. Hal ini berbeda halnya dengan pendapat Jarolimek, IPS di Sekolah Dasar tidak hanya mengintegrasikan konsep ilmu-ilmu sosial saja, tetapi juga humaniora dan sains serta berbagai isu-isu sosial di masyarakat.

Menurut Elliot (dalam Yeo dan Teng, 2015:1002), "social skills are often described as a set of abilities that enable children to respond in acceptable ways to certain social requests". Keterampilan sosial sering digambarkan sebagai seperangkat kemampuan yang memungkinkan anak-anak untuk merespon dengan cara yang dapat diterima untuk permintaan sosial tertentu. Jadi, keterampilan sosial juga diartikan sebagai kemampuan anak untuk merespon permintaan dengan cara mereka sendiri.

Patten (dalam Gregoriadis, dkk, 2013:40) mengungkapkan bahwa "no matter how gifted a child is physically or mentally, that child's happiness and success in life will also depend on his ability to get along with people", yang artinya tidak peduli seberapa berbakat anak secara fisik atau mental, kebahagiaan dan kesuksesan anak dalam hidup juga akan tergantung pada kemampuannya untuk bergaul dengan orang lain. Jika anak tidak pandai dalam bergaul dengan orang lain maka anak tersebut juga sulit untuk mencapai kesuksesan dan kebahagiaan.

Menurut Stephen dan Arnold (dalam Imron, 2014:61) kategori keterampilan sosial meliputi sebagai berikut. a. Environmental Behavior (perilaku terhadap lingkungan)

Kategori ini merupakan bentuk perilaku yang menunjukkan tingkah laku sosial individu dalam mengenal dan memperlakukan lingkungan hidupnya.

b. Interpersonal Behavior (perilaku interpersonal)

Kategori ini adalah bentuk perilaku yang menunjukkan tingkah laku sosial individu dalam mengenal dan mengadakan hubungan dengan sesama individu lain. Dalam keterampilan ini berhubungan dengan teman sebaya.

c. Self Related Behavior (perilaku yang berhubungan dengan diri sendiri)

Kategori ini merupakan bentuk perilaku yang menunjukkan tingkah laku sosial individu terhadap dirinya sendiri. Pada kategori ini dibagi menjadi dua bagian yaitu bertanggung jawab dan sikap positif terhadap diri sendiri.

d. Task-related Behavior (perilaku yang berhubungan dengan tugas)

Kategori ini merupakan bentuk perilaku atau respon individu terhadap sejumlah tugas akademis.

Adapun pengertian hasil belajar menurut Jihad dan Haris (2012:15) adalah perubahan tingkah laku siswa secara nyata setelah dilakukan proses belajar mengajar yang sesuai dengan tujuan pengajaran. Dalam proses belajar mengajar, siswa akan mengalami perubahan tingkah laku secara nyata seiring dengan tujuan pengajaran yang ingin dicapai. Sedangkan menurut Kunandar (2014:62) hasil belajar adalah kompetensi atau kemampuan tertentu baik kognitif, afektif, maupun psikomotorik yang dicapai atau dikuasai peserta didik setelah mengikuti proses belajar mengajar.

Sedangkan menurut Syah (dalam Kurniawan, 2014:22) faktor-faktor yang memengaruhi belajar dikelompokkan menjadi tiga kategori yaitu:

a. Faktor internal, yaitu faktor yang terdiri atas unsur jasmaniah (fisiologis) dan rohaniah (psikologis) siswa.

b. Faktor eksternal, yaitu faktor-faktor yang ada di lingkungan diri siswa yang meliputi lingkungan sosial dan lingkungan non sosial.

c. Faktor pendekatan belajar, yaitu meliputi strategi dan metode yang digunakan untuk melakukan kegiatan pembelajaran.

\section{METODE}

Penelitian tentang pengaruh model pembelajaran kooperatif tipe talking chips terhadap keterampilan sosial dan hasil belajar siswa kelas IV Sekolah Dasar ini merupakan jenis penelitian eksperimen. Dalam penelitian 
ini terdapat dua variabel, yaitu variabel bebas (independent) dan variabel terikat (dependent).

Rancangan penelitian eksperimen memiliki tujuan untuk mengungkapkan hubungan sebab akibat antar variabel. Adapun rancangan penelitian yang digunakan dalam penelitian eksperimen ini adalah penelitian quasi experimental design (eksperimen semu). Dalam penelitian ini, peneliti menggunakan teknik nonequivalent control group design.

Subjek penelitian ini adalah siswa kelas IV SDN Kedungsumur I dan SDN Kedungsumur III, Kecamatan Krembung, Kabupaten Sidoarjo. Sedangkan sampel penelitian ini adalah 20 siswa kelas IV SDN Kedungsumur I sebagai kelas kontrol dan 20 siswa kelas IV SDN Kedungsumur III sebagai kelas eksperimen. Penelitian ini berlokasi di SDN Kedungsumur I dan SDN Kedungsumur III, Kecamatan Krembung, Kabupaten Sidoarjo. Waktu penelitian akan dilakukan \pm 1 bulan pada semester genap tahun pelajaran 2015/ 2016.

Pengujian hipotesis digunakan untuk membandingkan antara kelas kontrol dan kelas eksperimen. Definisi hipotesis penelitian adalah jawaban sementara terhadap rumusan masalah penelitian. Setelah melakukan uji normalitas dan uji homogenitas, maka langkah selanjutnya adalah menguji hipotesis. Untuk menguji hipotesis, peneliti menggunakan rumus uji Independent Sample T-test dengan bantuan program SPSS 21.00.

Adapun menurut Sugiyono (2012:230) dasar pengambilan keputusannya yaitu:

a) Jika $t_{\text {hitung }}$ lebih besar dari $t_{\text {tabel }}$ ( $t_{\text {hitung }}>t_{\text {tabel }}$ ), maka hipotesis nihil (Ho) yang diajukan ditolak dan hipotesis alternatif (Ha) diterima.

b) $t_{\text {hitung }}$ lebih kecil dari $t_{\text {tabel }}\left(t_{\text {hitung }}<t_{\text {tabel }}\right)$, maka hipotesis nihil (Ho) yang diajukan diterima dan hipotesis alternatif $(\mathrm{Ha})$ ditolak.

\section{HASIL DAN PEMBAHASAN}

Penyusunan instrumen penelitian berupa angket keterampilan sosial siswa disusun berdasarkan kategori keterampilan sosial menurut Stephen dan Arnold (dalam Imron, 2014:61) yaitu (1) environmental behavior (perilaku terhadap lingkungan), (2) interpersonal behavior (perilaku interpersonal), (3) self related behavior (perilaku yang berhubungan dengan diri sendiri), (4) task-related behavior (perilaku yang berhubungan dengan tugas). Instrumen lembar angket terdiri dari 20 pertanyaan dan setiap kategori diwakili oleh lima butir pertanyaan.

Berdasarkan hasil penelitian, menunjukkan bahwa nilai mean keterampilan sosial siswa (pretest) pada kelas kontrol sebesar 57.0500 dan kelas eksperimen sebesar
58.3500. Adapun hasil uji Independent Sample T-test keterampilan sosial siswa (pretest) diperoleh $t_{\text {hitung }}(0.613)$ $<\mathrm{t}_{\text {tabel }}$ (1.686 pada df.38 dan taraf signifikansi 0,05). Karena taraf signifikasi $<0,05$ maka $\mathrm{H}_{0}$ diterima dan $\mathrm{Ha}$ ditolak. Hal ini menunjukkan bahwa tidak ada perbedaan keterampilan sosial siswa pada saat pretest di kelas kontrol dan di kelas eksperimen dikarenakan tidak ada perbedaan keterampilan sosial awal siswa baik di kelas kontrol maupun kelas eksperimen.

Berdasarkan hasil penelitian, menunjukkan bahwa nilai mean keterampilan sosial siswa (posttest) pada kelas kontrol sebesar 63.3500 dan kelas eksperimen sebesar 86.5500. Adapun hasil uji Independent Sample T-test keterampilan sosial siswa (posttest) diperoleh $t_{\text {hitung }}$ $(14.081)>t_{\text {tabel }}$ (1.686 pada df.38 dan taraf signifikansi $0,05)$. Karena taraf signifikasi $>0,05$ maka $\mathrm{H}_{0}$ ditolak dan Ha diterima. Hal ini menunjukkan bahwa ada perbedaan keterampilan sosial siswa pada saat posttest di kelas kontrol dan di kelas eksperimen dikarenakan adanya perlakuan (treatment) di kelas eksperimen yaitu pembelajaran menggunakan model pembelajaran kooperatif tipe talking chips, sedangkan di kelas kontrol tidak ada perlakuan (treatment). Jadi, dalam penelitian ini dapat disimpulkan bahwa keterampilan sosial siswa yang menggunakan model pembelajaran kooperatif tipe talking chips lebih tinggi secara signifikan dibanding dengan keterampilan sosial siswa yang menggunakan model pembelajaran konvensional.

Dari hasil penelitian tersebut menunjukkan bahwa keterampilan sosial siswa tinggi dengan menggunakan pembelajaran kooperatif tipe talking chips. Hal ini sesuai dengan penelitian terdahulu yang dilakukan oleh Mary Mwihaki Waiganjo, dkk (2015) bahwa penelitian tersebut menunjukkan hasil jika keterampilan sosial meningkat selama siswa menggunakan instruksi pembelajaran kooperatif. Namun terdapat perbedaan pada penelitian ini dengan penelitian terdahulu yaitu pada penelitian ini menggunakan pengembangan pembelajaran kooperatif yang lebih inovatif yang dapat menumbuhkan kerjasama, tanggung jawab terhadap tugas bersama, serta keaktifan siswa secara merata seperti yang diungkapkan oleh Huda (2012: 142) tentang tujuan dari model pembelajaran kooperatif tipe talking chips adalah untuk mengatasi hambatan pemerataan kesempatan yang sering mewarnai kerja kelompok.

Oleh karena itu, dapat disimpulkan bahwa penggunaan model pembelajaran kooperatif tipe talking chips berpengaruh terhadap keterampilan sosial siswa di Sekolah Dasar. 
Penyusunan tes hasil belajar ini dilakukan beberapa kali revisi untuk mendapatkan soal yang valid. Sugiyono (2013:168) mengungkapkan bahwa valid memiliki arti intrumen tersebut dapat digunakan untuk mengukur apa yang seharusnya diukur.

Berdasarkan hasil penelitian, menunjukkan bahwa nilai mean hasil belajar siswa (pretest) pada kelas kontrol sebesar 57.3500 dan kelas eksperimen sebesar 60.7000 . Adapun hasil uji Independent Sample T-test hasil belajar siswa (pretest) diperoleh $t_{\text {hitung }}(0.968)<\mathrm{t}_{\text {tabel }}$ (1.686 pada df.38 dan taraf signifikansi 0,05). Karena taraf signifikasi < 0,05 maka $\mathrm{H}_{0}$ diterima dan $\mathrm{Ha}$ ditolak. Hal ini menunjukkan bahwa tidak ada perbedaan hasil belajar siswa pada saat pretest di kelas kontrol dan di kelas eksperimen dikarenakan tidak ada perbedaan pada kemampuan awal siswa baik di kelas kontrol maupun kelas eksperimen.

Sedangkan nilai mean hasil belajar siswa (posttest) pada kelas kontrol sebesar 74.1000 dan kelas eksperimen sebesar 89.6500. Adapun hasil uji Independent Sample Ttest hasil belajar siswa (posttest) diperoleh $\mathrm{t}_{\text {hitung }}(6.798)>$ $\mathrm{t}_{\text {tabel }}$ (1.686 pada df.38 dan taraf signifikansi 0,05). Karena taraf signifikasi $>0,05$ maka $\mathrm{H}_{0}$ ditolak dan Ha diterima. Hal ini menunjukkan bahwa ada perbedaan hasil belajar siswa pada saat posttest di kelas kontrol dan di kelas eksperimen dikarenakan adanya perlakuan (treatment) di kelas eksperimen yaitu pembelajaran menggunakan model pembelajaran kooperatif tipe talking chips, sedangkan di kelas kontrol tidak ada perlakuan (treatment). Jadi, dalam penelitian ini dapat disimpulkan bahwa hasil belajar siswa yang menggunakan model pembelajaran kooperatif tipe talking chips lebih tinggi secara signifikan dibanding dengan hasil belajar siswa yang tidak menggunakan model pembelajaran kooperatif tipe talking chips.

Hasil penelitian tersebut menunjukkan bahwa hasil belajar siswa tinggi dengan menggunakan model pembelajaran kooperatif tipe talking chips. dalam proses belajar mengajar, hasil belajar penting untuk mengetahui pencapaian kompetensi yang telah ditentukan. Hal ini sesuai dengan pendapat Jihad dan Haris (2012:15) bahwa hasil belajar merupakan perubahan tingkah laku siswa secara nyata setelah dilakukan proses belajar mengajar yang sesuai dengan tujuan pengajaran.

Dalam penelitian terdahulu yang dilakukan oleh Yacob Hariyanto dan I Gusti Putu Asto (2011) juga menyatakan bahwa hasil belajar siswa yang dibelajarkan menggunakan model pembelajaran kooperatif tipe talking chips lebih baik dibandingkan dengan hasil belajar siswa yang dibelajarkan dengan model pembelajaran langsung. Jadi, penelitian ini sesuai dengan penelitian sebelumnya yang menyimpulkan jika hasil belajar siswa lebih tinggi dengan menggunakan model pembelajaran kooperatif tipe talking chips dibandingkan dengan model pembelajaran konvensional. Jadi, dapat disimpulkan bahwa penggunaan model pembelajaran kooperatif tipe talking chips berpengaruh terhadap hasil belajar siswa di Sekolah Dasar.

\section{PENUTUP}

\section{Simpulan}

Berdasarkan diskusi hasil penelitian yang telah dipaparkan, maka disimpulkan bahwa:

1. Hasil keterampilan sosial siswa dengan uji Independent Sample T-test pada saat pretest diperoleh thitung $(0.613)$ $<t_{\text {tabel }}$ (1.686) dengan signifikasi 0,05. Hasil tersebut menunjukkan bahwa tidak ada perbedaan keterampilan sosial siswa pada saat pretest di kelas kontrol dan di kelas eksperimen. Sedangkan hasil keterampilan sosial siswa setelah diberikan treatment atau perlakuan dan diberikan posttest diperoleh $\mathrm{t}_{\text {hitung }}(14.081)>\mathrm{t}_{\text {tabel }}$ (1.686) dengan signifikasi 0,05. Hasil tersebut menunjukkan bahwa ada perbedaan keterampilan sosial siswa pada saat posttest di kelas kontrol dan di kelas eksperimen sehingga disimpulkan bahwa model pembelajaran kooperatif tipe talking chips berpengaruh terhadap keterampilan sosial siswa Sekolah Dasar.

2. Hasil belajar siswa dengan uji Independent Sample Ttest pada saat pretest diperoleh $\mathrm{t}_{\text {hitung }}(0.968)<\mathrm{t}_{\text {tabel }}$ (1.686) dengan signifikasi 0,05 . Hal ini menunjukkan bahwa tidak ada perbedaan hasil belajar siswa pada saat pretest baik di kelas kontrol maupun di kelas eksperimen. Kemudian hasil belajar siswa setelah diberikan treatment atau perlakuan dan diberikan posttest diperoleh $t_{\text {hitung }}(6.798)>t_{\text {tabel }}$ (1.686) dengan signifikasi 0,05 . Hal ini menunjukkan bahwa ada perbedaan hasil belajar siswa pada saat posttest di kelas kontrol dan di kelas eksperimen sehingga dapat disimpulkan bahwa model pembelajaran kooperatif tipe talking chips berpengaruh terhadap hasil belajar siswa Sekolah Dasar.

\section{Saran}

Berdasarkan simpulan di atas dan pengalaman selama penelitian, maka peneliti dapat memberikan saran sebagai berikut:

1. Berdasarkan simpulan yang dipaparkan pada bab ini, maka model pembelajaran kooperatif tipe talking chips ini dapat dijadikan sebagai salah satu alternatif dalam pembelajaran untuk dapat meningkatkan keterampilan sosial dan hasil belajar siswa sehingga akan terwujud sebuah pembelajaran yang aktif, efektif dan menyenangkan. 
2. Bagi peneliti yang ingin meneliti lebih lanjut tentang pengaruh model pembelajaran kooperatif tipe talking chips dengan variabel yang sama diharapkan menggunakan materi yang berbeda sehingga keterampilan sosial dan hasil belajar dapat dilihat dari beberapa materi lain yang mempengaruhinya.

\section{DAFTAR PUSTAKA}

Fathurrohman, Muhammad. (2015). Model-Model Pembelajaran Inovatif: Alternatif Desain Pembelajaran yang Menyenangkan. Jogjakarta: Ar-Ruzz Media.

Gillies, Robyn M, dkk. (2008). The Teacher's Role in Implementing Cooperative Learning in the Classroom. USA: Springer Science.

Gregoriadis, Athanasios, dkk. (2013). Evaluating Preschooles' Social Skills: The Impact of a Physical Education Program from the Parents' Perspective. International Journal of Humanities and Social Science.Vol. 3 No. 10, pp. 40-51.

Huda, Miftahul. (2012). Cooperative Learning; Metode, Teknik, Struktur dan Model Terapan. Yogyakarta: Pustaka Pelajar.

Imron, Ilmawati Fahmi. (2014). Pengaruh Penerapan Pendekatan Scientific dengan Model Pembelajaran Berbasis Masalah terhadap Berpikir Kritis dan Keterampilan Sosial Siswa Materi Manusia dan Lingkungannya di Sekolah Dasar (Tesis tidak dipublikasikan). Universitas Negeri Surabaya.

Isjoni. (2013). Cooperative Learning. Pekanbaru: Alfabeta.

Jihad, Asep dan Abdul Haris. (2012). Evaluasi Pembelajaran. Yogyakarta: Multi Pressindo.

Kunandar. (2014). Penilaian Autentik (Penilaian Hasil Belajar Peserta Didik Berdasarkan Kurikulum 2013). Jakarta: Rajawali Pers.

Kurniawan, Deni. (2014). Pembelajaran Terpadu Tematik (Teori, Praktik, dan Penilaian). Bandung: Alfabeta.

Lie, Anita. (2008). Cooperative Learning (Mempraktikkan Cooperative Learning di Ruang-ruang Kelas). Jakarta: PT. Grasindo.

Sapriya. (2009). Pendidikan IPS Konsep dan Pembelajaran. Bandung: PT. Rosda Karya.

Subroto, Waspodo Tjipto. (2014). Bahan Pembelajaran Ilmu Pengetahuan Sosial di Sekolah Dasar. Surabaya: Unesa University Press.

Sugiyono. (2013). Metode Penelitian Pendidikan Pendekatan Kuantitatif, Kualitatif, dan $R \& D$. Bandung: Alfabeta.
Yeo, Kee Jiar dan Kie Yin Teng. (2015). Social Skills Deficits in Autism: A Study among Students with Autism Spectrum Disorder in Inclusive Classrooms. Universal Journal of Educational Research. Vol. 3 No.12, pp. 1001-1007. 